\title{
Fire-induced changes in soil and vegetation in the forest-tundra of Western Siberia
}

\author{
Oleg Sizov ${ }^{1}$, Leya Brodt $^{2}$, Andrey Soromotin ${ }^{2}$, Nikolay Prikhodko ${ }^{2}$, and Ramona Heim ${ }^{3}$ \\ ${ }^{1}$ Oil and Gas Research Institute RAS, 1193333 Gubkina st., Moscow, Russia \\ ${ }^{2}$ Universaty of Tyumen, 6250006 Volodarskogo st. Tyumen, Russia \\ ${ }^{3}$ Universaty of Munster, 481492 Schlossplatz st, Münster, Germany
}

\begin{abstract}
Wildfires are one of the main factors for landscape change in tundra ecosystems. In the absence of external mechanical impacts, tundra plant communities are relatively stable, even in the face of climatic changes. In our study, lichen cover was degraded on burnt tundra sites, which increased the permafrost thaw depth from 100 to $190 \mathrm{~cm}$. In old fire scars (burnt 1980 - 1990) of the forest-tundra, vegetation cover was dominated by trees and shrubs. The soil temperature on burnt forest-tundra sites was higher in comparison to conditions of the unburnt control sites and permafrost was was not found at a depth of 2-2,3m. Dynamics of the Normalized Difference Vegetation index (NDVI) from 1986-2020 reveal that immediately after fires, vegetation recovered and biomass increased due to the development of Betula nana shrubs. In old fire scars of the forest-tundra (burnt 1980-1990), a significant increase in NDVI values was evident, in contrast to the unburnt tundra vegetation where this trend was less pronounced. We conclude that "greening" in the north of Western Siberia may occur due to fire-induced transformation processes. The role of wildfires in the advance of the treeline to the north, driven by climate change and active economic development of the Arctic, will gradually increase in future.
\end{abstract}

\section{Introduction}

Wildfires are an important environmental factor, strongly influencing structure and distribution of vegetation, the intensity of the carbon cycle, and properties of the upper soil layer. Recent studies show that fires in the Arctic are one of the main reasons for permafrost degradation [1]. Under natural conditions, fires occur less frequent in tundra than in forest-covered taiga ecosystems [1, 2]. However, the frequency and intensity of tundra fires increase in direct proportion with anthropogenic impact, especially in areas of oil and gas production [3]. Even a single fire leads to strong changes in geochemical and geobotanical conditions of the Arctic landscape, which is characterised by low stability and a high potential of natural resources. Fire-induced changes in water regime, polar vegetation, and tundra and subboreal landscapes of the permafrost zone are the focus of very few studies [1]. We can highlight one study, conducted in the area of the Nadym region of the Yamalo-Nenets Autonomous Okrug [4], which showed that after fire, an intensive morphological change is observed in the upper soil layer, accompanied by a 
decrease of organic matter, and an enrichment with nitrogen. The impact of fire on foresttundra in the face of climate warming and greening processes of the Arctic remains poorly studied $[5,6]$.

To identify, monitor and assess wildfire impacts, remote sensing methods are commonly used, mainly based on remote sensing of the Earth (ERS) of medium and low resolution (Landsat-5,7,8, Sentinel-2,3, TERRA, AQUA, SuomiNPP, etc.) [2]. The handling of large amounts of information allows to estimate the forest-covered area on a global scale and with annual periodicity, using optical as well as radar data [7, 8]. Additionally, a retrospective analysis of changes can be performed, with the possibility to monitor the increase of burnt areas and the advance of shrubs and forest to the tundra (an increase in biomass and an increase in the degree of "greenness") [7]. For retrospective assessments, cloud-based geoplatforms are currently commonly used. Google Earth Engine allows to work with a complete archive of Landsat, MODIS, Sentinel data, as well as to conduct analytical operations and create applied projects (e.g. Global Forest Change, Global Forest Watch) [7]. In Russia, information systems for monitoring forest cover and forest fires based on remote sensing data are also existent $[10,11]$.

The aim of this work is to identify patterns of soil and vegetation changes in fire scars of different age, situated in the forest-tundra zone in the north of Western Siberia, based on field and remote sensing data.

\section{Territory and research methods}

The territory is efficient within the Nadym region of the Yamal-Nenets Autonomous Okrug (Yamalo-Nenets Autonomous Okrug) and covers the rivers Nyda and Pravaya Khetta (Fig. $1)$.

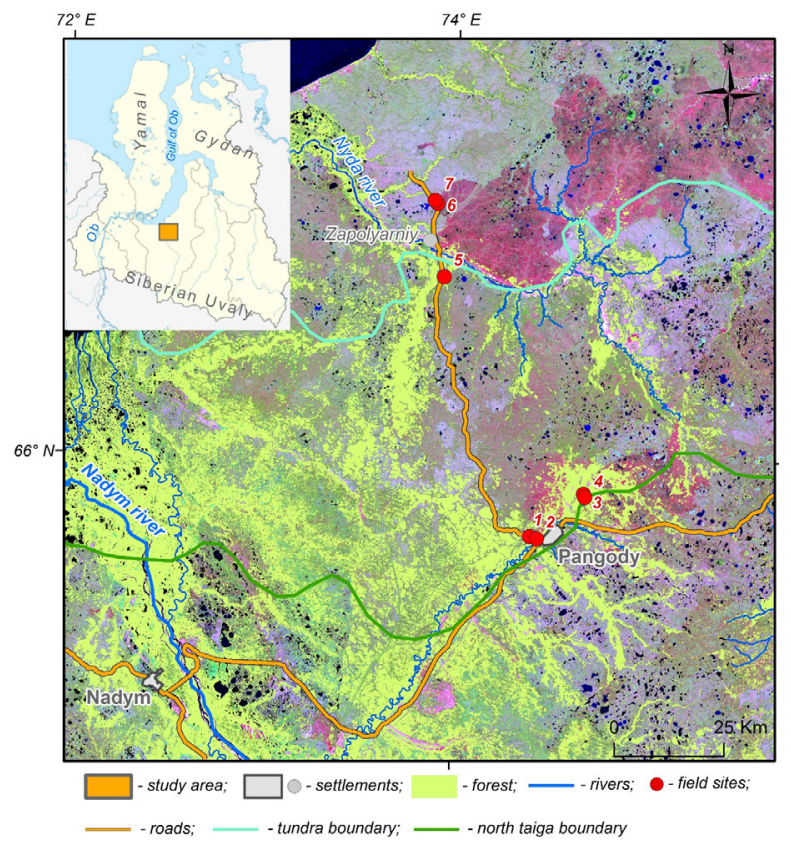

Fig. 1. Overview map of the study area (background - Landsat-8, 2018)

The surface relief is even with slight slopes, scattered with many swampy and lacustrine depressions. The upper part of the Quaternary sediments is represented by fluvio-glacial, marine and lacustrine-alluvial sediments. The thickness of organogenic peat deposits is on 
average 1-1.5 $\mathrm{m}$ (up to $5 \mathrm{~m}$ in depressions). Height above sea level ranges from 15-900 $\mathrm{m}$. The average annual temperatures are $-4.6-(+2)^{\circ} \mathrm{C}$, in summer the air warms up to $+14+$ $17^{\circ} \mathrm{C}$, in winter the average temperature is $-24-17^{\circ} \mathrm{C}$ (weather station Nadym). The study area is located on the border of continuous and discontinuous permafrost. Continuous permafrost occurs in interfluves and within uneven peatlands (temperature $-3-1{ }^{\circ} \mathrm{C}$ ). In valleys and on river terraces, the permafrost table is located at a depth of 50-150 $\mathrm{m}$ [12].

The study area is situated in the Tazovskoy southern tundra and Nadym-Purskaya forest-tundra provinces of the West Siberian Plain [12, 13].

Plant communities are represented by:

- dwarf birch and willow-dwarf moss-lichen tundra in combination with hummocky fractured-polygonal bogs and lichen-dwarf shrub woodlands (southern tundra formations);

- larch and spruce-larch shrub-moss woodlands in combination with lichen tundra (forest-tundra formations);

- larch and spruce-larch forests with cedar and pine, shrub-moss-lichen forests in combination with dwarf birch-sphagnum-lichen flat and large hillocky bogs (north taiga formations).

The anthropogenic impact is characterised by the development of large oil and gas fields (Medvezhye, Vostochno-Medvezhye). In addition, major gas pipelines (YamburgTula, Yamburg-Yelets, SRTO-Ural, Urengoy-Center, Urengoy-Uzhgorod, etc.) run through the study area.

Table 1. Study sites.

\begin{tabular}{|c|c|c|c|}
\hline $\mathbf{N}$ & Coordinates & $\begin{array}{c}\text { Date of field } \\
\text { investigations }\end{array}$ & Characteristic \\
\hline s. 1 & $\begin{array}{l}\text { N65 } 51^{\prime} 03,34^{\prime \prime} \\
\text { E74 } 22 ' 54,12^{\prime \prime}\end{array}$ & 16.08 .2020 & $\begin{array}{l}\text { Unburnt tundra vegetation } \\
\text { on the southern border of } \\
\text { the forest-tundra zone }\end{array}$ \\
\hline s. 2 & $\begin{array}{l}\text { N65 } 50^{\prime} 51,29^{\prime \prime} \\
\text { E74 } 25^{\prime} 01,67^{\prime \prime}\end{array}$ & 16.06 .2020 & $\begin{array}{l}\text { Forest-tundra site with fire } \\
\text { scars of } 1990 \text { on the site of } \\
\text { earlier burnt areas }\end{array}$ \\
\hline s.3 & $\begin{array}{l}\text { N65 } 56^{\prime} 13,04^{\prime \prime} \\
\text { E74 } 38^{\prime} 45,65^{\prime \prime}\end{array}$ & 17.08.2020 & $\begin{array}{l}\text { Forest-tundra site, which } \\
\text { burnt before } 1985\end{array}$ \\
\hline s. 4 & $\begin{array}{l}\text { N65 } 56^{\circ} 05,14^{\prime \prime} \\
\text { E74 } 39^{\prime} 16,27^{\prime \prime}\end{array}$ & 18.08 .2020 & $\begin{array}{c}\text { Forest-tundra site with fire } \\
\text { scars until } 1985 \text { and fire } \\
\text { scar of } 2016\end{array}$ \\
\hline s. 5 & $\begin{array}{l}\text { N66 } 32^{\prime} 10,5466^{\prime \prime} \\
\mathrm{E}^{\circ} 3^{\circ} 53^{\prime} 03,4520^{\prime \prime}\end{array}$ & 17.08 .2020 & $\begin{array}{l}\text { Forest-tundra site with fire } \\
\text { scars before } 1988 \text { in the site } \\
\text { of earlier burnt areas }\end{array}$ \\
\hline s.6 & $\begin{array}{l}\text { N653' } 19,93^{\prime \prime} \\
\mathrm{E}^{\circ} 54^{\prime} 17,22^{\prime \prime}\end{array}$ & 17.08 .2020 & $\begin{array}{l}\text { Southern tundra site with } \\
\text { fire scars of } 2016\end{array}$ \\
\hline s.7 & $\begin{array}{l}\mathrm{N} 65^{\circ} 32^{\prime} 09,38^{\prime \prime} \\
\mathrm{E}^{\circ} 52^{\circ} 50,36^{\prime \prime}\end{array}$ & 17.08 .2020 & $\begin{array}{l}\text { Unburnt tundra vegetation } \\
\text { at the southern border of the } \\
\text { tundra zone }\end{array}$ \\
\hline
\end{tabular}

To identify the characteristics of soil and vegetation recovery in the fire scars of different age in the forest-tundra zone, investigations were carried out at seven sites, which include both unburnt control sites and fire scars of different age (Fig. 1, Table 1). In each of the studied sites, we conducted geobotanical vegetation mapping and measured soil temperatures at different depths. Soil temperature was measured with a $\operatorname{Tr} 46908$ thermometer (TR di Turoni \& c. Snc, Italy) and drilling was carried out using a hand-held motor-drill Stihl BT 360 (Stihl, Germany). 
To assess the rate of vegetation recovery for each site, we calculated the Normalized Difference Vegetation Index (NDVI) from 1986-2020, using the Landsat data harmonization feature of Google Earth Engine. As study period, we chose the interval from June 30 to August 31. All available images in that period, with a quality threshold of more than $50 \%$, were used to calculate the median NDVI value.

\section{Results and discussion}

We found significant differences in vegetation and soil temperature (Fig. 2) between the studied sites.

Site s. 1 is characterised by unburnt tundra vegetation and is situated at the southernmost border of the forest-tundra zone in our study area. Betula nana dominates in the shrub layer (35\% of the total cover), Vaccinium uliginosum is the dominating the dwarf shrub species (15\% of the total cover), and a large part of the site is covered with Cladonia stellaris (more than $75 \%$ of the total cover). On this site, soil temperature was found to be negative $\left(-0.3^{\circ} \mathrm{C}\right)$ at a depth of $210 \mathrm{~cm}$. On the second unburnt control site, situated at the southern border of the tundra zone (s.7) $85 \%$ of the total cover was occupied by Cladonia stellaris. Permafrost was found at a depth of $120 \mathrm{~cm}$ (soil temperature of $-0.5^{\circ} \mathrm{C}$ ) and an ice lens $(5$ $\mathrm{cm}$ thick) was revealed by the borehole.

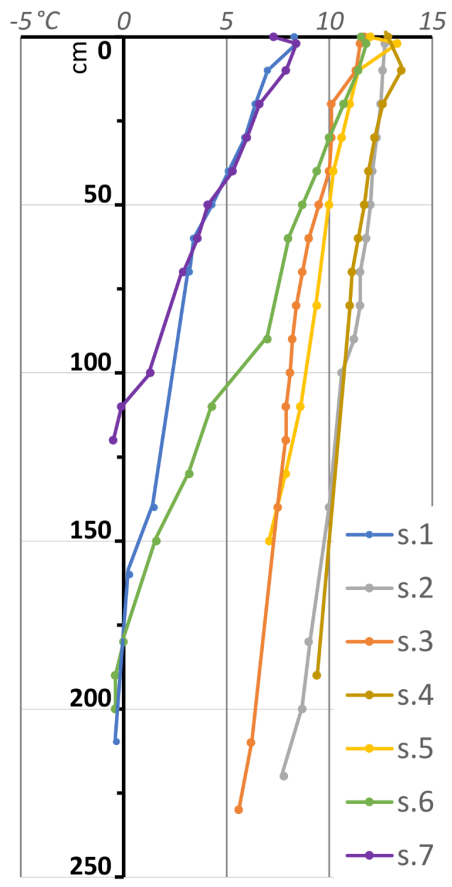

Fig. 2. Soil temperature at different depths of all seven site

In the site of the recently burnt fire scar (s. 6), burnt in 2016, Polytrichum commune occupies $70 \%$ of the total cover, and there are single specimens of Betula nana, Salix arctica, and Ledum palustre. The soil temperature in the upper part of the borehole is $3-4^{\circ} \mathrm{C}$ higher compared to the unburnt control conditions. Permafrost was found only at depths of $185-195 \mathrm{~cm}$.

In the forest-tundra site with the fire scar of 1990 (s.2), Betula nana occupies the main part of vegetation cover ( $40 \%$ of the total cover), there is a single specimen of Betula tortuosa, and the moss-lichen cover is practically absent. The minimum soil temperature at 
a depth of $210 \mathrm{~cm}$ was $8.1^{\circ} \mathrm{C}$. On the site of the burnt forest-tundra, where the fire event took place before 1985, Vaccinium uliginosum dominates the vegetation (s.2) (70\% of the total cover) and the moss-lichen layer occupies $2 \%$ of the total cover. Soil temperature at a depth of $210 \mathrm{~cm}$ amounts to $6.2^{\circ} \mathrm{C}$. Vegetation on the site in the northernmost part of the forest-tundra, which burnt before 1988 (p. 5), is characterised by Betula nana (40\% of the total cover) and Cladonia stellaris (18\% of the total cover). At a depth of $153 \mathrm{~cm}$, the soil temperature was $7.1^{\circ}$ C. Vaccinium uliginosum (40\% of the total cover) and Cladonia stellaris (53\% of the total cover) dominate the vegetation cover on the site of multiple fire events (before 1985 and in 2016). At a depth of $190 \mathrm{~cm}$, the soil temperature was $9.4^{\circ} \mathrm{C}$.

Median NDVI values for 1986-2020 show that in the unburnt control sites, the biomass is significantly lower than in the burnt sites (Fig. 3). In addition, in sites s.4 and s.6, the downward slopes, related the fires of 2016, are clearly visible. It can be noted that a gradual increase in NDVI values is evident in old fire scars at least since the late 1990s.

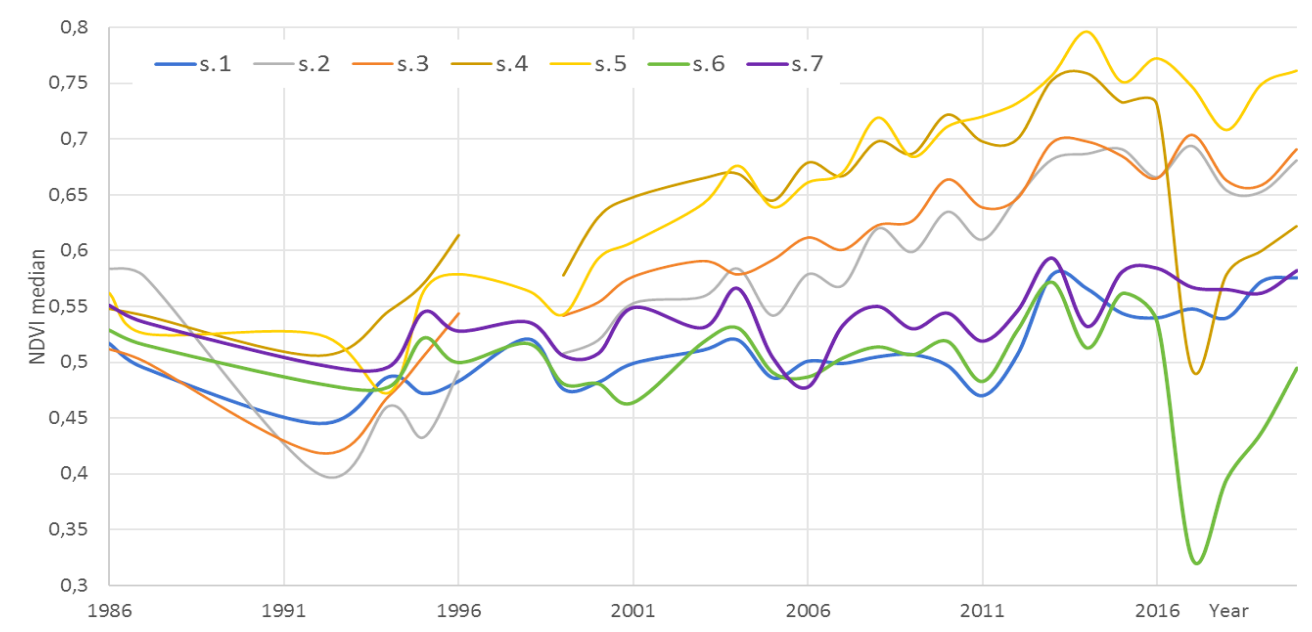

Fig. 3. Median NDVI values of tundra vegetation for fire scars of different age and unburnt control sites between 1986-2020 (based on Landsat data in Google Earth Engine).

In general, the unburnt control sites (s.1 and s.7) are characterized by the dominance of lichens (more than $70 \%$ of the total cover). At the same time, Betula nana occupies a significant proportion of shrub cover. On the recently burnt fire scar of 2016 (s.4), litter is characterised by burnt remnants, and lichen cover is practically absent (less than $5 \%$ of the total cover). At the same time, shrubs and dwarf shrubs show enhanced growth. On the burnt site within the tundra zone (s.6), Polytrichum commune occupies a large share of the site.

Permafrost conditions show clear differences. In the unburnt control sites s.1 and s.7, there is a sharp decrease in soil temperature to $2-3^{\circ} \mathrm{C}$ immediately below the surface, already at a depth of $100 \mathrm{~cm}$. For the tundra site with a recent fire scar (s.6), an increase in the soil temperature of the upper part of the soil strata was found in comparison with the unburnt control site by $4-5^{\circ} \mathrm{C}$, while the depth of the permafrost is comparable to the unburnt control site (s.1). For the site of multiple burns, soil temperature is significantly higher, and the gradient of its decrease is less compared to the unburnt control site. Permafrost is only detected at depths below $2-2.3 \mathrm{~m}$.

NDVI dynamics from 1986-2020 show two main features:

- vegetation recovery and an increase in NDVI values are observed after fire, mainly due to shrub encroachment (Betula nana) (areas s.4 and s.6);

- for forest-tundra sites with old fire scars (1980-1990), NDVI values increase significantly in comparison to the unburnt control tundra vegetation, where this trend is 
much less pronounced. I.e. "greening" of the tundra on a local scale occurs, in particular, due to fire-induced changes.

In many studies, conducted on the territory of Yakutia and Alaska, a recovery of the permafrost and the original tundra communities, on fire scars, is noted. However, there are also examples for biomass growth, shrub encroachment and the development of forests in tundra ecosystems after fires $[14,15,16]$. In this study, we found a clear tendency of tundra vegetation towards shrub encroachment and the development of forest in the forest-tundra zone as a result of fire-induced effects. At the same time, the degradation of permafrost and an increase in soil temperature does not occur immediately after a fire, but gradually, as the root system of shrubs and trees develops. In this case, the fire acts only as a primary factor in disrupting the protecting effect of the lichen cover.

\section{Conclusion}

Tundra plant communities in the north of Western Siberia are characterised, in the absence of external mechanical influences, by high stability, despite the observed climatic changes. The main factor for the possible replacement of tundra plant communities by secondary plant communities are natural fires. Post-fire succession leads to further degradation of the permafrost due to the development of the root system and an increase in the thermal conductivity of soils under conditions of a steady increase in average annual air temperatures. Our results confirm the presence of shrub expansion and a decrease of lichen cover after fires, both in short- and long-term recovery after fire of the forest-tundra in the north of Western Siberia. Within the face of climate change and the economic development of the Arctic, the role of wildfires in the tundra as one of the factors of landscape change will increase. Recent developments in remote sensing make it possible to develop an objective system for long-term fire monitoring and the assessment of post-fire changes in vegetation, in order to prevent negative ecological consequences.

This study was funded by RFBR according to the research project № 20-55-71004 and Belmont Forum project № 1729 SERUS.

\section{References}

1. I. Nitze, G. Grosse, B.M. Jones, V.E. Romanovsky, J. Boike. Remote sensing quantifies widespread abundance of permafrost region disturbances across the Arctic and Subarctic, Nature Communications, Vol. 9 No. 1, pp. 1-11 (2018)

2. A.V. Rocha, M.M. Loranty, P.E. Higuera, M.C. Mack, F.S. Hu, B.M. Jones, A.L. Breen, E.B. Rastetter. S.J. Goetz, G.R.Shaver. The footprint of Alaskan tundra fires during the past half-century: implications for surface properties and radiative forcing, Environmental Research Letters, Vol. 7, No. 4, pp. 1-8 (2012)

3. M.K. Raynolds, D.A. Walker, K.J. Ambrosius, J. Brown, K.R. Everett, M.Kanevskiy, G.P. Kofinas, V.E. Romanovsky, Y. Shur, P.J. Webber/ Cumulative geoecological effects of 62 years of infrastructure and climate change in ice-rich permafrost landscapes, Prudhoe Bay Oilfield, Alaska, Global Change Biology. Vol. 20, No. 4, pp. 1211-1224 (2014)

4. E. Abakumov, A. Pechik, E. Chebyakina(Maximova), G. Shamilishvili. Effect of the Wildfires on Sandy Podzol Soils of Nadym Region, Yamalo-Nenets Autonomous District, Russia. Applied and Environmental Soil Science, Vol. 2020 (https://doi.org/10.1155/2020/8846005) 
5. P.D. Jones, D.H. Lister, T.J. Osborn, C. Harpham, M. Salmon, C.P. Morice. Hemispheric and large-scale land-surface air temperature variations: An extensive revision and an update to 2010, Journal of Geophysical Research: Atmospheres, Vol. 117, No. D5, pp. 1-29 (2012)

6. J.A. Sobrino, Y.Julien, S.García-Monteiro. Surface Temperature of the Planet Earth from Satellite Data, Remote Sensing, Vol. 12, No. 2, pp. 1-10 (2020)

7. M.C. Hansen, P.V. Potapov, R. Moore, M. Hancher, S.A. Turubanova, A. Tyukavina, D.Thau, S.V. Stehman, S.J. Goetz, T.R. Loveland, A. Kommareddy, A. Egorov, L.Chini, C.O. Justice, J.R.G. Townshend. High-Resolution Global Maps of 21stCentury Forest Cover Change, Science, Vol. 342, No. 6160, pp. 850-853 (2013)

8. M. Shimada, T. Itoh, T. Motooka, M. Watanabe, S. Tomohiro, R. Thapa, R. Lucas. New global forest/non-forest maps from ALOS PALSAR data (2007-2010), Remote Sensing of Environment, Vol. 155, pp. 13-31 (2014)

9. H. Epstein, U. Bhatt, M. Raynolds, D. Walker, J. Pinzon, C.J. Tucker, B.C. Forbes, T. Horstkotte, M. Macias-Fauria, A. Martin, G. Phoenix, J. Bjerke, H. Tømmervik, P. Fauchald, H. Vickers, R. Myneni, T. Park, C. Dickerson. Tundra greenness, Bulletin of the American Meteorological Society, 2018, Vol. 99, No. 8, pp. 165-169.

10. E.A. Loupian, S.A. Bartalev, I.V. Balashov, V.A. Egorov, D.V. Ershov, D.A. Kobets, K.S. Sen'ko, F.V. Stytsenko, I.G. Sychugov. Sputnikovyi monitoring lesnykh pozharov v 21 veke na territorii Rossiiskoi Federatsii (tsifry i fakty po dannym detektirovaniya aktivnogo goreniya) (Satellite monitoring of forest fires in the 21st century in the territory of the Russian Federation (facts and figures based on active fires detection)), Sovremennye problemy distantsionnogo zondirovaniya Zemli iz kosmosa (Current problems in remote sensing of the Earth space), Vol. 14, No. 6, pp. 158-175 (2017)

11. I.V. Balashov, A.V. Kashnitskii, S.A. Bartalev, S.S. Bartalev, M.A. Burtsev, I. I. Vorushilov, V.A. Egorov, V.O. Zharko, D.A. Kobets, A.M. Konstantinova, E.A. Loupian, I.A. Saigin, K.S. Senko, F.V. Stytsenko, I.G. Sychugov, S.A. Khvostikov, T.S. Khovratovich. VEGA-Les: information system for complex monitoring of forests and hunting grounds in Russia. Sovremennye problemy distantsionnogo zondirovaniya Zemli iz kosmosa (Current problems in remote sensing of the Earth space). Vol. 17, No. 4, pp. 73-88 (2020)

12. Atlas Yamalo-Nenetskogo avtonomnogo okruga (Atlas of the Yamal-Nenets Autonomous Okrug), Moscow: GUGK, 248 p (2004)

13. I.S. Il'ina, E.I. Lapshina, N.N. Lavrenko Rastitel'nyi pokrov Zapadno-Sibirskoi ravniny (Vegetation of the West Siberian Plain), Novosibirsk: Nauka, 248 p (1985)

14. R.E. Hewitt, T.N. Hollingsworth, F.S. Chapin, D.L. Taylor. Fire-severity effects on plant-fungal interactions after a novel tundra wildfire disturbance: implications for arctic shrub and tree migration, BMC ecology, Vol. 16, pp. 1-25 (2016).

15. S.M. Landhausser, R.W. Wein, Postfire Vegetation Recovery and Tree Establishment at the Arctic Treeline: Climate-Change-Vegetation-Response Hypotheses, Journal of Ecology, Vol. 81, No. 4, pp. 665-672 (1993)

16. R. J.Heim, A.Bucharova, L.Brodt, J.Kamp, D.Rieker, A.V. Soromotin, ... \& N.Hölzel. Post-fire vegetation succession in the Siberian subarctic tundra over 45 years. Science of The Total Environment, 143425 (2020) 